\title{
THE DIRECTING ANIMATION FILM ENTITLED SI JOE
}

\author{
Satria Veriansyah Wiguna ${ }^{1}$ and Ranang Agung Sugihartono ${ }^{2}$ \\ ${ }^{1}$ Indonesian Insitute of the Arts Surakarta, Indonesia \\ ${ }^{2}$ Indonesian Insitute of the Arts Surakarta, Indonesia \\ E-mail correspondence: ranang.as@gmail.com
}

\begin{abstract}
The re-introduction of the Nusantara folklore is very important because it is a form of the original culture of the archipelago and a national identity. An animated film work that tells the story of a parody about Timun Mas folklore is expected to be able to reintroduce a folklore from Central Java by adding novelty to the portrayal of the characters and stories. The making of this work aims to create a $2.5 \mathrm{D}$ animated film with the theme of folklore with new packaging. The artistic creation doing by the director is to combine and move $2 \mathrm{D}$ animation in a $3 \mathrm{D}$ space perspective, so that $2.5 \mathrm{D}$ animation is created. 2.5D animation was created using a virtual camera so that it produces better image movement than an ordinary $2 \mathrm{D}$ animation. This animation work that explores the folklore of the archipelago shows success in aspects of the uniqueness and impression in the visualization and novelty of the story. This animated film can bring back the old story so it is enjoyable to watch by millennial audiences.
\end{abstract}

Keywords: Folklore, parody, directing, Si Joe, and animation.

\begin{abstract}
ABSTRAK
Pengenalan kembali cerita rakyat Nusantara sangat penting dilakukan karena merupakan wujud budaya asli Nusantara serta menjadi identitas bangsa. Karya film animasi yang bercerita tentang parodi cerita rakyat Timun Mas diharapkan mampu mengenalkan kembali sebuah cerita rakyat dari Jawa Tengah dengan menambahkan kebaruan pada penggambaran karakter dan ceritanya. Pembuatan karya ini bertujuan untuk menciptakan film animasi $2.5 \mathrm{D}$ bertema cerita rakyat dengan kemasan baru. Kreasi artistik yang dilakukan sutradara yaitu menggabungkan dan menggerakkan animasi $2 D$ pada perspektif ruang $3 D$, sehingga tercipta animasi $2.5 D$. Animasi $2.5 \mathrm{D}$ diciptakan dengan menggunakan kamera virtual sehingga menghasilkan pergerakan gambar yang lebih baik daripada animasi 2D biasa. Karya animasi yang mengeksplor cerita rakyat Nusantara ini menunjukkan keberhasilan dalam aspek keunikan dan daya tarik dalam visualisasi dan keterbaruan cerita. Film animasi ini dapat memunculkan kembali cerita lama tersebut sehingga enak ditonton oleh khalayak milenial.
\end{abstract}

Kata kunci: Cerita rakyat, parodi, penyutradaraan, Si Joe, dan animasi.

\section{Introduction}

The Nusantara (archipelago) has diverse traditions and cultures from east to 


\section{Artistic}

west / Sabang to Merauke. This diversity makes Indonesia has many folklore that are rich in life values. "Folklore is a part of Indonesia's cultural wealth in general and literary wealth in particular that needs to be explored and disseminated. Unfortunately the effort to explore the Indonesian folklore has not been attempted by many people" (Astrid, 1978). even though these stories are the nation's identity and many positive values can be obtained from the story. Lately, in Indonesia many stories are packed through entertaining shows such as television soap operas, movie, series films, Film Television (FTV), and short films. However, the story mostly revolves around the romance of modern drama, and it is rare to take up stories based on folklore adaptations or existing folklore. This can have an impact on the sinking of the existence of the Indonesian's folklore.

An effort is needed to reintroduce folklore to the public, especially to the children, because children are the next generation of the nation. They need folklore in the future as their identity. Media in a new format is needed so that the media attracts attention and suits the tastes of the times. Variative and interesting stories according to segmentation can be used as a spice so that the audience is increasingly interested.

A breakthrough is needed to reintroduce folklore stories from ancestral heritage. One of them is by making a new treatment for example by parodying folktales and refreshing the characters through animated films. The original story of Timun Mas has more perspective on the life of Mbok Sarni as the protagonist, while the life of the Buta Ijo (Green Ogre) side has not been told. For 6 years, Buto Ijo waited for the size of Timun Mas's baby, what activities he carried out, and his lifestyle.

The idea of the story in the mind of the writer as a director is the Joe who is a green giant, or in Javanese terms also referred to as Buto Ijo as in the original story. Buto Ijo has given Mbok Sarni a cucumber seed to plant so Mbok Sarni can have a child. The story is more about how the life of Joe while waiting and watching Timun Mas until she was 6 years old. The Joe is always in the cave where he lives while observing the growth and development of Timun Mas whose house is in a field that is located quite far away from Joe's cave, but the Joe can still observe from afar. 
The director also thinks that the wealth of Indonesia is in everyday language which is a reflection of the culture of each region. The making of this animated film also applies the language used in the form of Javanese Ngoko or Javanese everyday, because the original story of Timun Mas also originated from Central Java.

\section{Literature Review}

A director is the key to the project of a production or filmmaking. "The director is responsible for all creative aspects of the film, controls the overall contents and plot of the film, makes direction to talents (drawing artist, background artist, voice actor, editor, and special effects) and manages the film cinematography" (Suyanto \& Yuniawan, 2006). The point is that every director really has to work extra in every filmmaking, even though animated films.

A book entitled Directing Animation: Everything You Didn't Learn in Art School by Tony Bancroft, mentions some of the tasks of an animation director, television series director, or short film director are:

They all have one important thing in common; they all have to share and enforce their vision to a crew of not-so-like-minded artists. The thing that makes directing difficult and wonderful at the same time is working with all of the unique personalities in your creative team and getting them focused in one direction (Bancroft, 2014).

The main task of a director is to communicate with the production team and monitor how the animation results are achieved. The animation director is also responsible and ensures how the shape and impression from the beginning of the project takes place so as to produce the desired work. Of course a director still has to work extra. The director's work depends on how the director directs and communicates with all the crew involved.

The making of this animated film combines and composes 2D and 3D elements in such a way using a computer or can also be called a digital compositing process. $2.5 \mathrm{D}$ is a term that arises from the merging of $2 \mathrm{D}$ with $3 \mathrm{D}$. Media in the form of $2 \mathrm{D}$ and 3D animation can stand alone or can be combined with one another. The difference between the two animations is that $2 \mathrm{D}$ animation is a collection of flat images that 


\section{Artistic}

only have two-dimensional space, and is drawn using two $\mathrm{x}-\mathrm{y}$ axis. While $3 \mathrm{D}$ is an animation that uses objects that are in three-dimensional space or have three $\mathrm{x}-\mathrm{y}-\mathrm{z}$ axis to move.

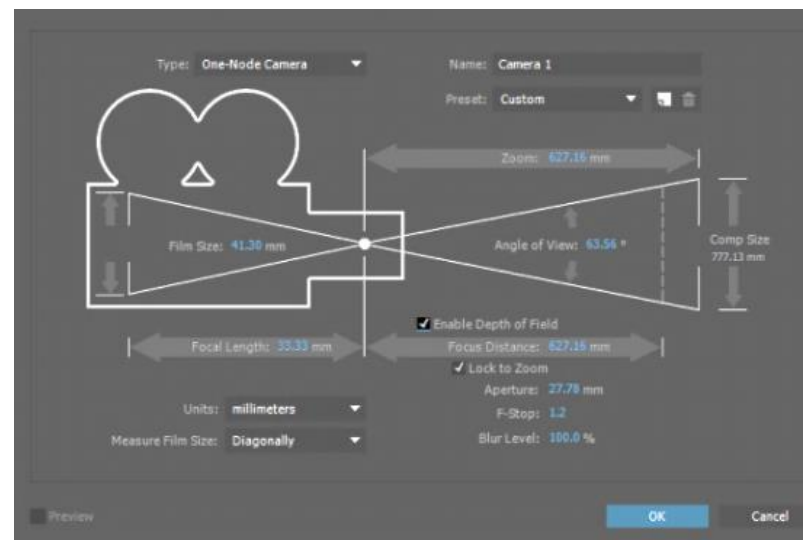

Figure 1. Virtual camera settings in After Effect

The definition of $2.5 \mathrm{D}$ animation is technically described by Adrien-Luc Sanders in his article on the animation.about.com site as follows.

Basically, 2.5D animation is 2D animation in a 3D space. Sometimes this involves actually moving 2D-animated objects in a 3D space; sometimes it involves using clever tricks of perspective and shadow to make 2D space look like 3D space, although you're still working on a 2D plane (Sanders, 2015).

The movement of 2D objects in three-dimensional space can also be a way of manipulating perspective and using shadows to $2 \mathrm{D}$ objects to make it look like there is a $3 \mathrm{D}$ space effect even though it is made on a flat space.

The 2.5D animation crosses the line between 2D and 3D animation, and creates an attracting sense of depth. This can involve anything from building perspective of 3D scenes through the use of character shadows to creating fake perspectives and three-dimensional sense using small tricks that make your characters and objects appear to occupy 3D space instead of flat space.

Basically, the making of this animated film is $2 \mathrm{D}$ animation, but in a $2 \mathrm{D}$ movement or 2D animation, it only has an $\mathrm{x}-\mathrm{y}$ axis, while a virtual camera makes it possible to capture or record a virtual set and environment with an $\mathrm{x}-\mathrm{y}-\mathrm{z}$ axis or $3 \mathrm{D}$. The use of virtual cameras in 2D animated films, can provide 3D space effects. Just as 
Adrien Luc Sanders (2015) explained about 2.5D, where 2.5D animation is a 2D animation that moves in 3D space, then the use of a virtual camera is very suitable for making 2.5D effects in a 2D animated film. The virtual camera is an amazing tool that can create almost any shot that your imagination can conjure up. However, to take a page from the Spider-Man comics, 'with great power comes great responsibility (Donati, 2007). Jason Donati stated that a virtual camera is an amazing tool that is able to realize all types of shots that exist in the one's imagination. A virtual camera can also be defined as a recording device that has the ability of an ordinary camera but is more complex and flexible because the shape is not physical but a software. This is becoming the director's consideration when choosing and using a virtual camera in this animated film. Achievement of several shots that have elements of fantasy that is difficult to realize if in the conventional way without using a virtual camera.

\section{Creation Methodology}

At this stage of making animated films as well as the stages of film making in general, consisting of preproduction, production, and post-production. The director is also involved in each stage, tasked with overseeing as well as giving direction to the crew to get the maximum results, so that each outcome of a stage depends very much on how the director directs his crew at work. Animation director is the leader and director of a production team consisting of animators, designers, models, and postproduction artists (Prayogo \& Sugihartono, 2016). Beside overseeing the process of production, the director is also very influential in the creative process found at each stage of production. The creative process can be done by adding something new and different from what already exists in a script and storyboard. This aims to strengthen the story that will be visualized.

During the production phase, the director supervises the making of an animatic which is a rough animation, which contains a reference to the duration and scene, making it easy for the production stage to work on the animation, from visual work to audio. Animatic is created when the script and storyboard are ready. The director plays a role in directing the visual composition of each shot. 


\section{Artistic}

When entering the production and postproduction stages, the director divides into two main divisions, namely the visual and audio divisions. The visual division includes the process of drawing keyframes + in between, animating, coloring, and digital compositing. Meanwhile, the audio division works on voice casting, recording, foley $+\mathrm{sfx}$ and music compositing. The two main divisions can work at the same time in separate places using animatic guidance to save work time and energy spent by the crew. After the two divisions are completed in carrying out their tasks, the results are combined so as to create audio visual works in the form of animated films. In addition, it also features an opening and closing credit title, as well as a DVD cover design and movie poster. Both of these stages, the writer as a director carries out the oversight function from upstream to downstream, as the opinion states that all this is in addition to the main responsibility of creatively directing the entire process of a production, from storyboards to the final delivery of animation (Levy, 2014).

\section{Discussion}

\subsection{Parodying Timun Mas's Story}

The effort to reintroduce the folklore of Nusantara by providing novelty and a little bit changing the perspective of the original story is one of the ideas of the director in creating this animated film work. The story of Timun Mas was chosen by the director because in terms of the story it has a good moral message and also has a tense action, especially when the story arrived at Timun Mas being pursued and fighting Buta Ijo with various magic potions given by Mbok Sarni. Several things in Timun Mas's story have been explored by the director to be able to include various scenes that are more interesting and not boring.

Before making a storyboard, the director who is also a script writer makes observations around, aiming to find interesting and funny things that can be included in the story. The director made more observations through the internet, especially on social media that discussed a phenomenon that was being discussed or viral. The director also observed that the media discussing something that is viral had more readers or viewers because of the curiosity of netizens. Then the result of observations 
included in the story of this animated film. The director gets quite a lot of comedy inspiration from memes that are circulating and viral on social media, such as about the rise of online motorcycle taxi and the rise of Indian soap operas.

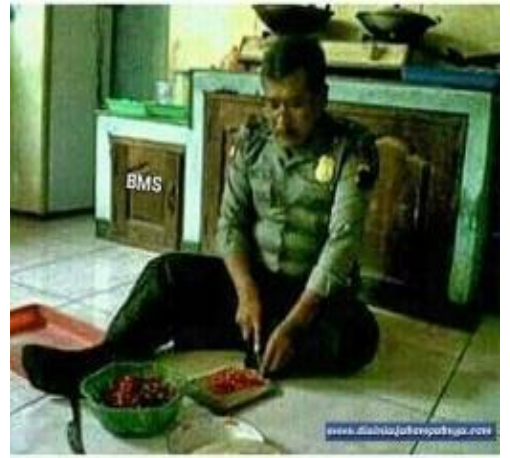

Setiap sore istriku males masak ini semua karena FILM UTTARAN

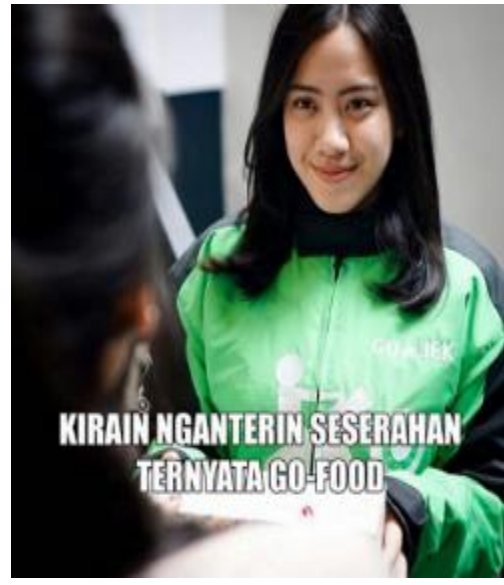

Figure 2. Meme is an inspiration for writing a script (Reference: http://www.yukepo.com \& http://www.mistergalau.com)

The author is inspired by the famous animated film titled Shrek produced by Dreamworks, where the main character is actually an ogre or ugly giant who always lives alone. A giant is always considered evil, man-eaters and other bad things. But Shrek's character is the opposite, Shrek turns out to be a good, polite, and funny giant even though it was told scary initially. This unique aspect is able to make many viewers fall in love with Shrek's character. This is proven by the wide screen film that has been worked on up to 4 sequels, and also the serial film. The idea emerged to apply some of Shrek's uniqueness to the characters in the animated film Si Joe. For that reason, the writer makes the figure of the Buta Ijo as the protagonist who is entertaining and not frightening, and is expected to give something fresh to the folklore of Timun Mas.

Previously the director had also made an inspiration search for character design references. The director saw and read several films and comics that had giant figures. In addition, the director also observed how the form and visual of Buta Ijo found in Javanese culture. The search and observation opens up new ideas about character design for the character of Joe. In addition, the search for references was carried out 


\section{Artistic}

focusing on typical Central Javanese clothes, namely simple kebaya commonly worn by female and female farmers. The reference is needed to make Mbok Sarni and Timun Mas's character designs. More references are sourced from the director's experience when he was in a rural area, then supplemented with a visual reference search using the internet.

There are three main characters in this animated film, they are Si Joe, Mbok Sarni, and Timun Mas. Si Joe's character is Buta (green ogre) who lives in Central Java. The story's creation in this film is that the giant is kind-hearted although he looks rather scary, like the main character in the film Shrek, who combines elements of ancient legends with today's life. Reference in the form of Buta in ancient Java which has characteristics such as long hair, fangs soaring up, green and large body are combined with contemporary references, such as t-shirts, jackets, and jeans.

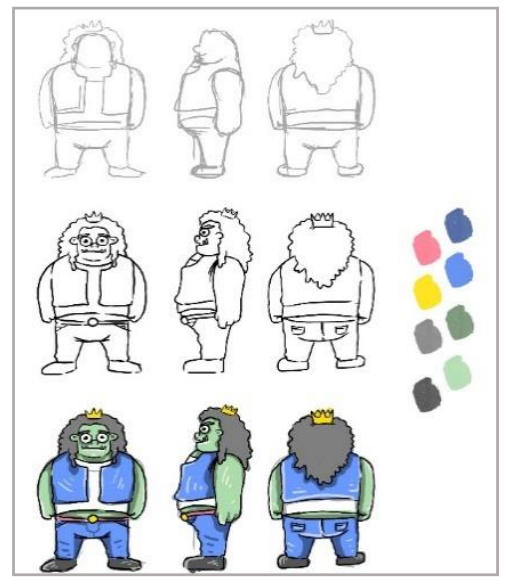

Figure 3. Joe's character design

Mbok Sarni's character is described as an old widow who lives alone as a farmer in the middle of her garden. The clothes worn by Mbok Sarni's character are adjusted to his profession as a farmer. They are simple clothes that do not require ornaments and the colors are not too flashy. Mbok Sarni's hair color is gray, a mixture of black and white which means Mbok Sarni's hair is not entirely white. Sometimes Mbok Sarni wears a head veil when she is gardening to plant something. 


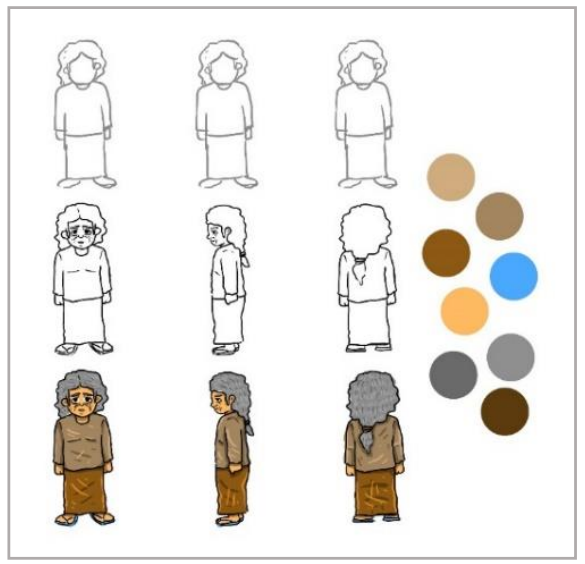

Figure 4. Character design of Mbok Sarni

Timun Mas's character is a typical of a young girl who is described as active and full of enthusiasm. Timun Mas is a child raised by Mbok Sarni, so the clothes she wears are also simple, using only a shirt with a simple vest and skirt. In addition, the clothes are combined with shoes and small socks that allow this character to move more actively and freely. Timun Mas's clothes are bright green and pink in order to give the impression that Timun Mas has a cheerful character and is always upbeat.

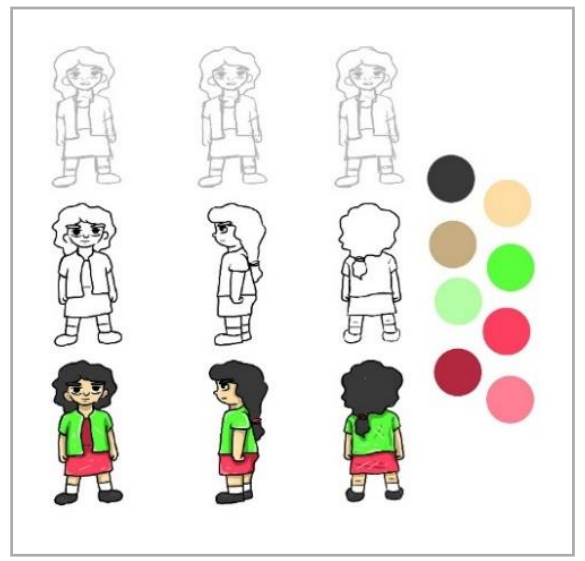

Figure 5. Timun Mas character design

In addition to character design, environment design is also created through director's observation. The manuscript describes the living place of Buta Ijo is on the hill, while Mbok Sarni's house is under the hill, an area that fits the description of the location is the Harau Valley in the Lima Puluh Kota Regency, West Sumatra Province. 


\section{Artistic}

Harau Valley has a flat rice field and surrounded by high cliffs that rise straight up. The director also researched several similar places via the internet, such as Mount Pegat (Gunung Pegat) in Blitar and the Breksi cliff in Yogyakarta.
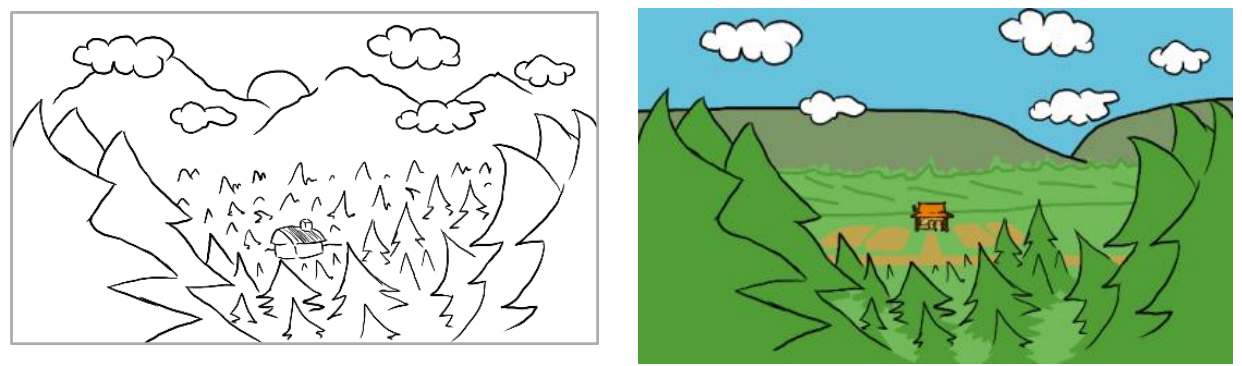

Figure 6. One of the design environments in Si Joe's film

These three places are considered as references for the design setting of Si Joe's story. The director found that from all the references available, Harau Valley was the place that could be most used as a reference in drawing backgrounds. The choice of colors that are predominantly green for forest images and blue for bright skies. The atmosphere is expected to build a cheerful atmosphere for this film. When the afternoon, the sky looks more yellow and the green is rather dark.

The following are the specifications about the work of animated films titled $\mathrm{Si}$ Joe:

Title of Film : Si Joe

Program : Short animated film

Duration $\quad: 11$ minutes

Theme : Folklore

Segmentation : Children, all ages

Characteristics : Parody

Synopsis:

Si Joe is a Green Ogre "Buta Ijo" who lived in ancient Java. Joe's life changed after he gave seeds to be planted to mbok Sarni. Si Joe waited up to 6 years to meet Timun Mas. During the 6 years spent by Joe, he did a lot of things that invited laughter. When picking up Timun, Si Joe instead get resistance from Timun Mas. 


\subsection{Making 2.5D Animation}

The making of this animated film begins with the first stage, that is a preproduction which contains a search for ideas, scripts, storyboards and animatic. In this stage which takes the longest time is animatic. Animatic is an early example of an original story that has been created to ensure that the story is appropriate and the time is exactly right. The work is done by the writer himself, because animatic is the key of what the director wants to convey to the other crew.

Making Animatic uses applications such as Adobe Flash CC 2015 and After Effect CC 2015. The selection of the 2 applications is based on the crew's habit of working using those applications so that it increases the efficiency of work time. Images from the storyboard are traced into vector images using Adobe Flash then moved frame by frame. Provision of motion blur effects and virtual camera delivery using Adobe After Effect. After the animatic is finished, the next step is to provide the actual picture and sound.

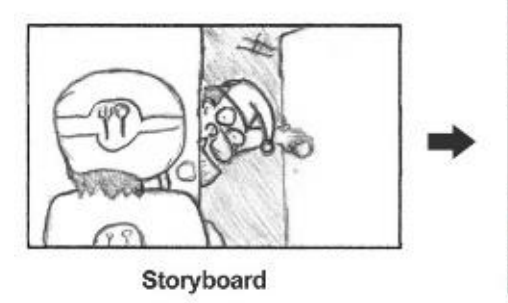

Storyboard

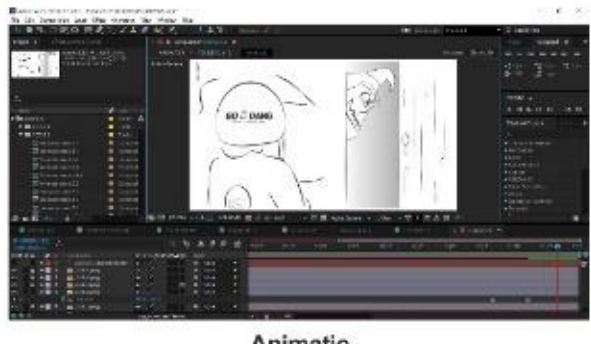

Animatic

Figure 7. Making animatic of scene 2 shot 11 with Adobe After Effect

Furthermore, the production process in this animated film covers 2 main divisions, visual and audio. The director in this film is responsible for making the production process run smoothly, and as much as possible to reduce production costs and the duration of the work process, because the crew working in this animated film project is a faculty friends with the director, and is not treated as a professional worker.

The production process starts from the visual division that is making key images or commonly called keyframes. This work is done by illustrator. Because the animation created is basically $2 \mathrm{D}$ animation, the illustrator draws a keyframe using 


\section{Artistic}

Adobe Photoshop applications with the raster format with the help of hardware in the form of a pen tablet. The raster format has the advantage that the process is very similar to drawing on a piece of paper with a pencil. This is faster because drawing does not require nodes to connect the spots with one another. In addition, this technical way of drawing using Photoshop is already very well-known by illustrators and writer, so that time efficiency can be achieved

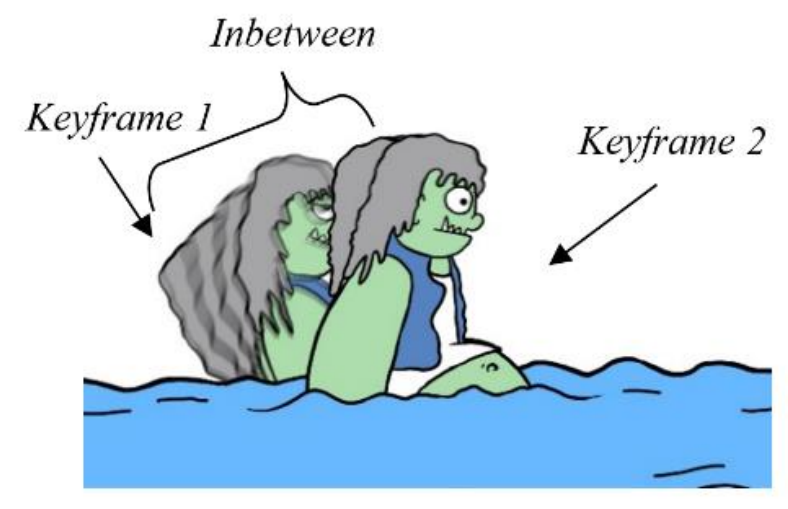

Figure 8. Keyframe and inbetween scene 8 shot 15

The coloring process in this animated film goes through several stages, namely the basic color stage, enhanced color, and color grading. The base color is done with a tendency towards solid or flat colors, not yet containing gradations and shading effects. The basic color used by the animator when working on the animating process, because if you wait for an enhanced color, can result in more time consuming. After the base color is finished, the illustrator further enhances the coloring process, such as giving shading effect, gradation and so on. When enhancing the colors, the director pays attention to the color logic. If an object gets closer to light, the color will be brighter. Color grading is processed when entering the postproduction stage or the process of giving visual effect.

Beside the use of cameras, this animated film also relies on lighting as an important element in the world of cinematography. The resulting color is then processed by digital lighting to produce richer and more realistic color gradations.

Animating process is done after the director gets the results from the keyframe and inbetween images that have been perfect. The process of arranging frame by frame 
using Adobe Flash into a movement, then explored into the format *.swf (shockwave flash) with a transparent background. Format *.swf is a file extension produced by Adobe Flash applications that are usually in the form of an animation, game, and other interactive media. The *.swf file extension can also be included in After Effect. After the animating process is completed and becomes the *.swf format, the next step is digital image compilation (digital compositing) using After Effect.

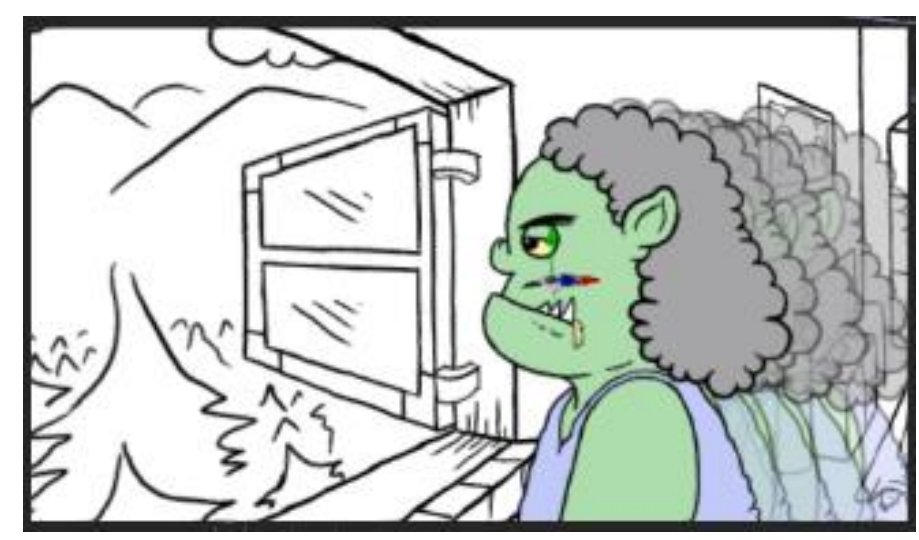

Figure 9. Making automatic inbetween with Adobe After Effect

The use of motion graphic techniques in digital compositing can speed up the process of animating, because it is very rare for illustrators to draw one by one inbetween as a whole, with the help of software on a computer in the form of mathematical calculations can make inbetween created automatically.

Another way the director makes inbetween is directing the illustrator to break down each part of the objects that wil be moved, for example for the movement of character that are walking, then the character image is separated between the body, legs, hands and so on as needed. Once split, then the objects are moved one by one using motion tween in After Effect and then put together into a unity in accordance with the design about the way the character walks. In addition, other elements such as background, foreground, and lighting are also drawn separately and combined in the digital compositing process. 


\section{Artistic}

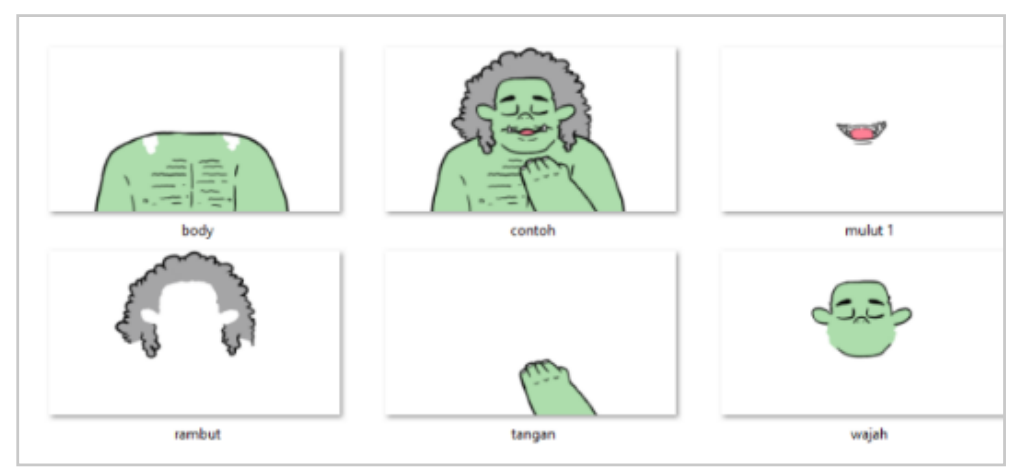

Figure 10. Fraction of objects that will be moved by motion

Explanation of Steve Wright (2013) in his book titled Digital Compositing for Film and Video that a digital compositing process is to combine many images in one lighting condition and one camera, then the digital compositing process must be held by a DOP person. This process is carried out after all of the visual elements are ready such as character animation, background and foreground images, but still supervised by the director.

The first step in the digital compositing process is to combine all of visual elements first, or in the live action film process it can be called a blocking process. After Effects application has three axis $\mathrm{x}, \mathrm{y}, \mathrm{z}$ which means it has 3D space that can be used to make blocking. In accordance with 3D logic that provides near-far effects, the placement of an object and character must be in accordance with the existing floorplan. The background is always placed farthest from the camera, the foreground is placed closest to the camera, while the movement of characters or important objects is placed between the background and the foreground. Blocking step is carried out on each shot.

After the blocking step is completed, the camera setting is carried out in a digital compositing process, such as setting the position, angle, camera movement, and the focus of the camera. Storyboard becomes the main reference in adjusting the camera angle. There are more facilities in virtual camera settings on After Effect than physical camera facilities in ordinary films. Placement of the camera position becomes unlimited, can be anywhere, move anywhere and be able to handle all the needs, types 
and shot techniques. The camera techniques used are steady, tilting, tracking, zoom in-out, follow and focus track. The movement of the camera is done by animating like animate an ordinary object, which uses a keyframe and motion tween.

The character color and background processing is done not only during the coloring process, but also done secondly in time during the lighting process. This is intended to produce richer and more realistic colors, in harmony with the $2.5 \mathrm{D}$ effect. The lighting used is light which beautifies a shot in accordance with settings such as the flare effect. Shading in this film is not very important. Making shadows only done during the coloring process. Lighting can be done at the digital compositing stage, after moving the camera is completed.

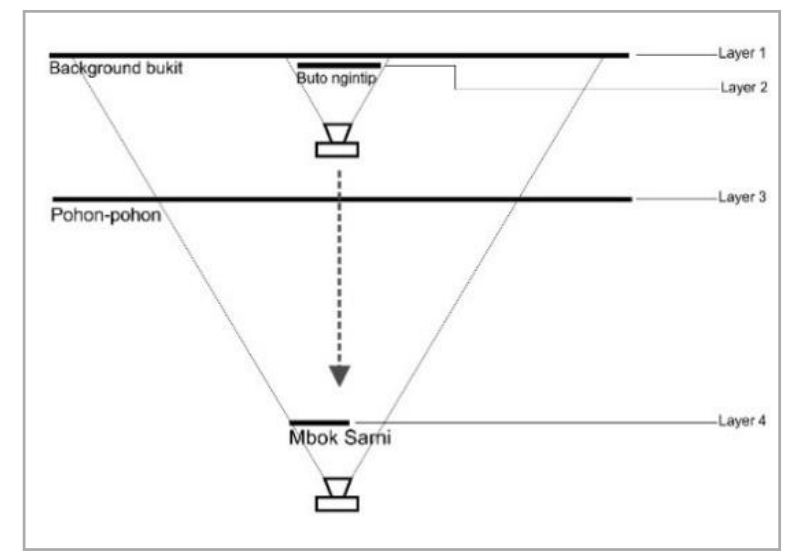

Figure 11. Blocking scene 2 shot 14 in Si Joe's movie

Thus the process of making 2.5D animation, in essence the animation created is $2 \mathrm{D}$ animation, but moves in $3 \mathrm{D}$ space and is recorded into a virtual camera frame.

\subsection{Directing Si Joe's Animated Film Dialogue}

Beside overseeing the process during visual production, the role of the director is also required during the voice recording process. In making animated films the dubbing process is usually underestimated, even though good quality dubbing and dialogue can improve the quality of animated films. In voice recording process of animated film Si Joe is assisted by a voice dubbing director or can be called a voice director. 


\section{Artistic}

Previously, the voice director observed the character designs, film scripts, and finally animatics that had been made before. When looking at the character design visually, it can be read about how the sounds are suitable for filling the voice of each character. The types and characters of suitable voice for animated films are identified by the voice director.

The director wants the character of the Buta Ijo who is a Buta (ogre) with a very large voice, has a bass and firmly in accordance with the logic of the body posture of the Buta Ijo that is also large or giant. Mbok Sarni's character should have old voice or sound old, but she can scream and be more funny naturally. And, Timun Mas's character must have a small voice and talkative.

Voice director and director have criteria for people who are suitable for joining the casting, then they are invited to do casting. The voice casting process is carried out by the director and voice director by listening directly to the voice of the dubber candidates who are asked to read the script, and also read it with expression.

After getting all matching dubbers and establishing an agreement, then proceed to the next process. Voice directors train all dubber on how to process sound through several stages. These stages include reading scripts with expressions, demonstrating scenes in accordance with animatic, and practicing in adjusting the duration and expression of character. Training is needed to simplify, familiarize the dubber and save time during the voice recording process carried out in the recording studio.

Pre-recording exercises are very important to do to simplify the recording process. The more exercises dubbers do, the dubber can become more accustomed to speaking as the director and voice director want. The director directs them to use everyday language that is usually done by Dubber. It is intended to make dialogue

flexible, natural, and avoiding unnatural voice. The language used is Javanese Ngoko, so that Dubber produces dialogue with confidence and smoothly. During exercise sessions, dubber can also get used to the recording device, because during exercise the dubber also uses the recording device as a reference. In making this animated film, dubber exercise is done 5 times, which is about 3 hours per exercise. 


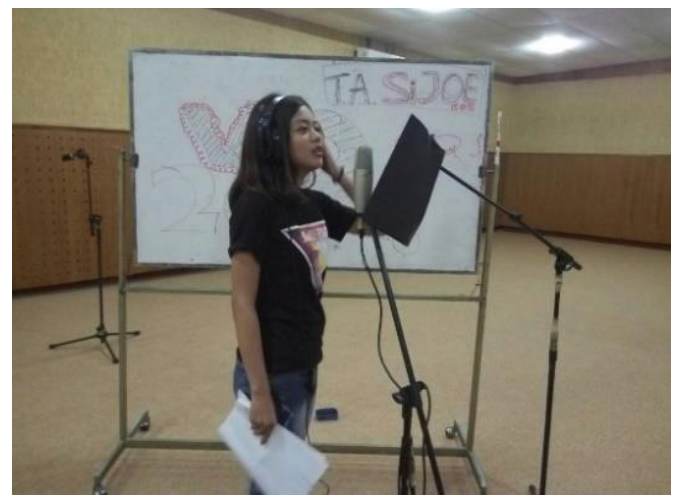

Figure 12. Timun Mas voice actor in recording (Photo: Riza Budi Utomo, 2017)

During the voice recording, the voice director is accompanied by the director, together they are directing the Dubbers to make the voice of this animated film character with the most natural sound. This is important because the film is an animated film with characters that are portrayed in a cheerful atmosphere. The sound that is made must also be exaggerated and has an emphasis on each character, such as the Ogre's voice that must be large and firm; Mbok Sarni's voice, an old widow, her voice must be soft and frail; and Timun Mas's funny and cute voice because of the child character.

Each character has their own technique in the process of filling in the sound. The making of the Ogre character's voice using the chest breathing technique and releasing it in the lowest possible tone to create a character that has bass and firm voice. The voice of Mbok Sarni's character has a technique that is folding the tongue while talking to produce an old or unpowerfull effect. And, Timun Mas's character is a character that has a high tone and as much as possible funny like a child. The voice actor of this character does already have a high tone character, just a little acting cute to produce Timun Mas's character voice.

Beside the voice of character dialogue, another important sound element is the voice of ambience or also called the bacgkround sound, as well as the detailed sound and sound effects (SFX) handled by the foley artist. Supporting voices are also needed to make the audience feel in the mood, setting the atmosphere or the situation of a shot 


\section{Artistic}

in this animated film.

The foley process requires tools and materials that are able to make sounds similar to those in the animatic, such as shoes and mud that produce footsteps, pillows that are hit produce thumping sounds and so forth. The foley process is done by recording the desired sound while looking at the animatic shows to match the duration. Foley sound effects are sounds that are synchronized with the display film on the screen and require the expertise of a Foley editor to record correctly (Sugihartono \& Wibawa, 2019).

Some audio elements are combined into one process, so that it can add to the atmosphere more dramatic in this animated film. Whether good or not the sound quality produced in the recording process certainly cannot be separated from the director, who participated in giving advice and direction. In addition, teamwork is also very influential in the smoothness of each production process.

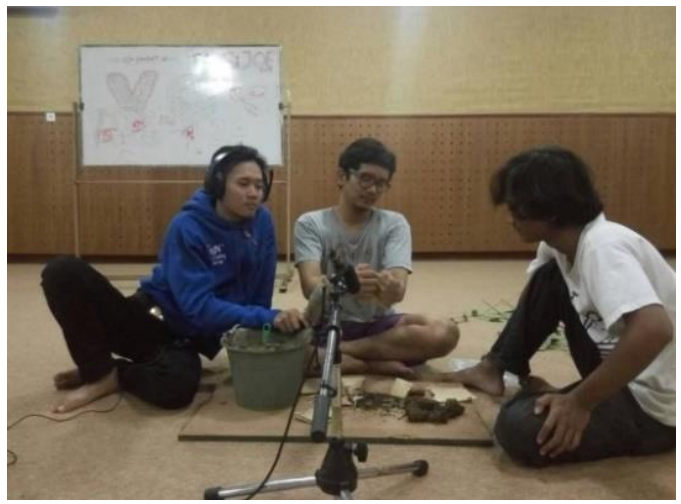

Figure 13. Foley artist take the sound of the ground cracking effect

(Photo : Rian Rajawali, 2017)

\section{Conclusion}

Indonesia is one of the countries that have a great deal of cultural diversity. From this diversity came up the creative products, one of which was in the form of folklore that developed and circulated widely in society since ancient times. Folklore is one of the ancestral heritage which must be preserved because through the folklore the true local cultural identity is stored.

Research in the form of searching for story ideas is an important start for the 
final result of an art work. The easiest idea seeking is something that touches on the nearest life phenomenon of the workman himself. After finding an idea that departs from the closest phenomena, then the idea is applied by the director to the popular folklore called Timun Mas, so that it is expected to be able to reintroduce various folklore from Indonesia or Nusantara that may have been drowned by the popularity of fairy tales from abroad.

The director made this animated film Si Joe by using the $2.5 \mathrm{D}$ effect. The effect made by creating 3D space to compose 2D objects with the help of a virtual camera. The process of making the $2.5 \mathrm{D}$ effect is at the production stage, that is the animating $\&$ digital compositing process. The use of 2.5D can make this animated film have depth through camera movement as it is commonly used in making live action films in general. In addition, the use of logical lighting is also used by the director to get maximum results.

Storytelling using parody is an approach taken by the director with the purpose to entertaining the audience, because parody is closer to comedy. The director is required to explore the story and then describe the atmosphere of the film which is unique in terms of time setting, such as at the depiction of the Ogre's technology that uses brick to order food through online couriers.

From the creation of art work done by updating folklore (the story of Timun Mas), this can produce a unique and interesting story. This strategy can be used to explore other Nusantara folklore. Beside producing unique stories, the archipelago folklore that has been explored can be introduced again to make it suitable to be watched by audiences in the millennial era. And the further benefits are that the original story is not forgotten (stay preserve).

\section{References}

Bancroft, T. (2014). Directing for Animation. Focal Press.

Donati, J. (2007). Exploring Digital Cinematography. Cengage Learning.

Levy, D. B. (2014). Directing Animation. Allworth Press.

Prayogo, K. I., \& Sugihartono, R. A. (2016). Directing Animation dalam Film Seri 


\section{Artistic}

Seribu Satu Candi. CAPTURE : Jurnal Seni Media Rekam, 8(1), 34-47.

Sanders, A. L. (2015). What is Animation 2.5D?

http://animation.about.com/od/faqs/f/what-is-2-5d-animation.html/

Sugihartono, R. A., \& Wibawa, A. (2019). Editing: Film, Televisi, dan Animasi. Graha Ilmu.

Suyanto, M., \& Yuniawan, A. (2006). Merancang Film Kartun Kelas Dunia. Penerbit Andi. 